\title{
Stocking density in the larviculture of Nile tilapia in saline water
}

\section{Ronald Kennedy Luz', Walisson de Souza e Silva ${ }^{1}$, Reinaldo Melillo Filho', André Eduardo Heringer Santos ${ }^{1}$, Lucas Alves Rodrigues ${ }^{1}$, Rodrigo Takata ${ }^{1}$, Érika Ramos de Alvarenga ${ }^{1}$, Eduardo Maldonado Turra ${ }^{1}$}

\footnotetext{
${ }^{1}$ Universidade Federal de Minas Gerais, Escola de Veterinária, Laboratório de Aquacultura, CP 567, 30123-970, Belo Horizonte, MG, Brazil.
}

ABSTRACT - The objective of this study was to assess the possibility of increasing the stocking density in the larviculture of Nile tilapia, Oreochromis niloticus, in saline water. Six-day post-hatched larvae (average weight of $0.09 \pm 0.002 \mathrm{~g}$ ), at the start of the exogenous feeding, were stocked in twelve $8 \mathrm{~L}$ tanks at densities of 1, 10, 20 and 30 larvae/L. The larvae were fed a diet consisting of $40 \%$ crude protein five times per day. During larviculture, water was kept at a salinity of $2 \mathrm{~g}$ of common salt/L. At the end of the 28-day experiment, the survival rate, length, weight, temperature, water salinity and conductivity were not affected by the different treatments. The dissolved oxygen and $\mathrm{pH}$, however, decreased as density increased, whereas total ammonia concentration, turbidity and biomass showed a direct relationship with the increase of stocking density. Consequently, the present study shows for the first time that the larviculture of Nile tilapia is possible with up to 30 larvae/L in water with $2 \mathrm{~g}$ of salt/L.

Key Words: intensive larviculture, Oreochromis niloticus, water quality, water salinity

\section{Introduction}

Stocking density is one of the factors that could potentially affect fish survival (Houde, 1977) and production performance (Hecht \& Uys, 1997; Irwin et al., 1999; Luz \& Zaniboni Filho, 2002), so it must be considered when determining the economic profitability of production systems (Carvalho et al., 1997; Baskerville-Bridges \& Kling, 2000; Gomes et al., 2000). Furthermore, the use of the appropriate density is a commercially beneficial operation, focusing on maximizing the utilization of the rearing system, water and financial resources (Fairchild \& Howell, 2001).

Nile tilapia, Oreochromis niloticus, is one of the most cultivated species in the world. This is due to their rusticity, fast growth, high-quality flesh and wide acceptance in the consumer market. Moreover, its larviculture is simplified by the use of formulated diets from the start of exogenous feeding (Hayashi et al., 2002; Meurer et al., 2005). However, experiments on nutrition or sexual inversion for intensive larviculture systems has been done at low stocking densities (Mainardes-Pinto et al., 2000; Meurer et al., 2005), and when the effect of density is assessed, the literature shows conflicting results, but in general, relatively low densities, from 1 to 10 larvae/L, are recommended (Sanchez \& Hayashi, 1999; El-Sayed, 2002; Tachibana et al., 2008). These densities are not appropriate for intensive rearing in a laboratory, where there are usually space limitations.
Apart from stocking density consideration, the use of low salinities is also beneficial in rearing larvae (Luz \& Santos, 2008; Santos \& Luz, 2009) and juvenile freshwater fish, a fact which can be explained by the decrease of the ionic difference between the animal and the external environment (Boeuf \& Payan, 2001). Furthermore, in salinity environments, the toxicity of nitrogenous compounds is reduced (Sampaio et al., 2002).

Thus, the objective of this study was to evaluate the possibility of intensifying Nile tilapia larviculture by increasing stocking density in saline water.

\section{Material and Methods}

The experiment was conducted at the Aquaculture Laboratory (LAQUA) of the Department of Animal Science, School of Veterinary Medicine, Universidade Federal de Minas Gerais-UFMG, Brazil.

Six-day post-hatched larvae $(0.09 \pm 0.002 \mathrm{~g}$ weight and $8.2 \pm 0.3 \mathrm{~mm}$ length) were counted and transferred to twelve $8 \mathrm{~L}$ tanks in a static system with supplementary aeration and mounted in a thermostatic bath. Densities of 1, 10, 20 and 30 larvae/L were tested, in a completely randomised design with three replications per treatment.

Larvae were fed five times a day, every two hours from $8 \mathrm{~h} 00$, with a commercial diet containing $40 \%$ crude protein at a daily rate equivalent to $30 \%$ of the biomass of the tank. 
During the larviculture, the water was kept at a salinity of $2 \mathrm{~g}$ of salt $/ \mathrm{L}$, using non-iodised common salt $(\mathrm{NaCl})$. The tanks were cleaned twice a day, before the second and the last feedings. In each cleaning, $80 \%$ of the water volume of the tanks was replaced with water of the same salinity and temperature prepared daily and measured with a Multiparameter probe (YSI MOD6920V2).

The physical and chemical parameters of the water, such as temperature, $\mathrm{pH}$, salinity, conductivity, dissolved oxygen and turbidity, were monitored weekly using a Multiparameter probe (YSI MOD6920V2). The analysis of total ammonia nitrogen was performed once a week, in the morning before tank cleaning, according to the methodology (APHA, 2005).

At the end of the 28th day of the experiment, the biometrics of the fingerlings (weight and total length) were obtained, and survival was determined by counting the individuals. In order to record weight and length, the fingerlings were anaesthetised with eugenol $(50 \mathrm{mg} / \mathrm{L})$, measured with an electronic caliper (Starrett) and weighed on an analytical precision scale.

Data were analysed for normality using the Lilliefors test and for homoscedasticity using the Cochran test. Once appropriate for parametric analysis, the data were subjected to linear regression analysis.

\section{Results}

The average values of water temperature, salinity and conductivity were similar for the various densities $(\mathrm{P}>0.05)$ (Table 1). The average values of dissolved oxygen and
$\mathrm{pH}$ were inversely proportional to the density, while the turbidity and total ammonia showed a direct relationship to the increase of density. The concentration of total ammonia, however, did not affect the final average weight of the fingerlings, which were similar among the different treatments $(\mathrm{P}<0.05)$ (Figure 1).

Likewise, the densities being tested did not affect the survival and final length of the fingerlings $(\mathrm{P}>0.05)$ (Table 2). As a result, the increase in biomass produced by the treatment was directly proportional to the stocking density.

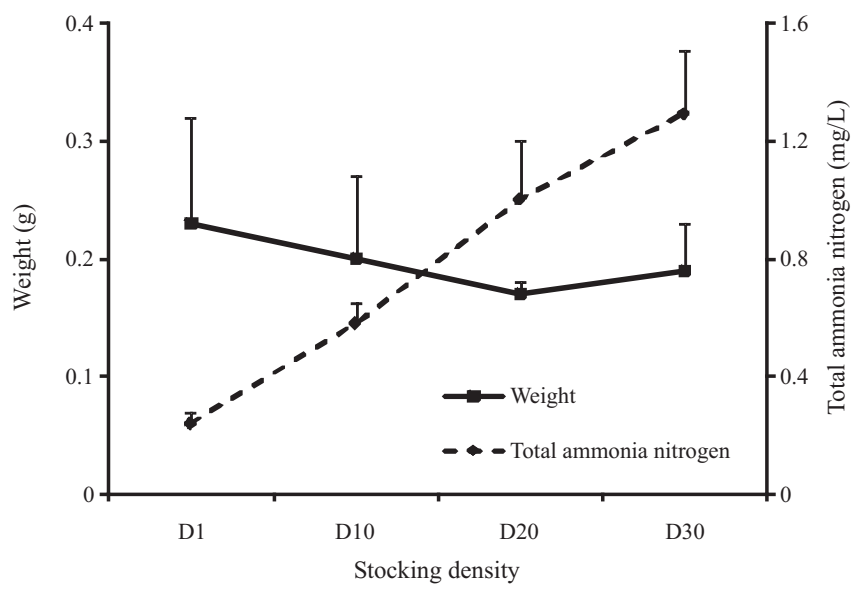

The equation $\mathrm{y}=0.22+0.036 \mathrm{x}$ (adjusted $\mathrm{R}^{2}=99.45 \%$ ) represents the results of the total ammonia concentration at the different stocking densities.

D1 - 1 larvae/L; D10 - 10 larvae/L; D20 - 20 larvae/L; D30 - 30 larvae/L.

Figure 1 - Average weight $(\mathrm{P}>0.05)$ of the Nile tilapia and total ammonia nitrogen concentrations $(\mathrm{P}>0.05)$ at stocking densities.

Table 1 - Water quality during larviculture of Nile tilapia at different stocking densities

\begin{tabular}{|c|c|c|c|c|c|c|c|c|}
\hline \multirow{2}{*}{ Item } & \multicolumn{4}{|c|}{ Density (larvae/L) } & \multirow{2}{*}{$\mathrm{CV}(\%)$} & \multicolumn{3}{|c|}{$\mathrm{P}_{\text {value }}{ }^{1}$} \\
\hline & 1 & 10 & 20 & 30 & & Linear & Quadratic & Cubic \\
\hline Temperature $\left({ }^{\circ} \mathrm{C}\right)$ & 28.55 & 28.66 & 28.59 & 28.80 & 0.53 & 0.115 & 0.711 & 0.321 \\
\hline Conductivity $(\mathrm{mS} / \mathrm{cm})$ & 4.12 & 4.09 & 4.08 & 4.14 & 0.98 & 0.491 & 0.106 & 0.563 \\
\hline Salinity (g of salt/L) & 2.02 & 2.00 & 2.00 & 2.02 & 1.07 & 0.888 & 0.121 & 0.740 \\
\hline Dissolved oxygen $(\mathrm{mg} / \mathrm{L})^{2}$ & 8.35 & 8.07 & 7.73 & 7.11 & 4.34 & 0.002 & 0.515 & 0.829 \\
\hline $\mathrm{pH}^{3}$ & 8.16 & 8.06 & 7.91 & 7.81 & 1.16 & 0.001 & 0.876 & 0.702 \\
\hline Turbidity (NTU) ${ }^{4}$ & 2.31 & 6.75 & 9.53 & 10.63 & 22.5 & 0.000 & 0.103 & 0.906 \\
\hline
\end{tabular}

$\mathrm{CV}$ - coefficint of variation.

${ }^{1}$ Linear, quadratic and cubic order effects in relation to the increase of larvae/L

${ }^{2} \hat{\mathrm{Y}}=8.45-0.041 \times \mathrm{X}\left(\mathrm{r}^{2}=0.95\right)$.

${ }^{3} \hat{Y}=8.18-0.012 \times X\left(r^{2}=0.98\right)$.

${ }^{4} \hat{\mathrm{Y}}=2.98+0.28 \times \mathrm{X}\left(\mathrm{r}^{2}=0.88\right)$.

Table 2 - Survival, final length and biomass of Nile tilapia at the end of 28 days of larviculture at different stocking densities

\begin{tabular}{|c|c|c|c|c|c|c|c|c|}
\hline \multirow{2}{*}{ Item } & \multicolumn{4}{|c|}{ Density (larvae/L) } & \multirow{2}{*}{ CV $(\%)$} & \multicolumn{3}{|c|}{$\mathrm{P}_{\text {value }}{ }^{1}$} \\
\hline & 1 & 10 & 20 & 30 & & Linear & Quadratic & Cubic \\
\hline Survival (\%) & 87.50 & 69.23 & 70.10 & 76.53 & 16.97 & 0.417 & 0.146 & 0.678 \\
\hline Length (mm) & 23.20 & 21.51 & 20.98 & 19.27 & 12.32 & 0.112 & 0.945 & 0.747 \\
\hline $\operatorname{Biomass}(\mathrm{g})^{2}$ & 13.38 & 96.10 & 157.84 & 288.38 & 43.03 & 0.000 & 0.649 & 0.585 \\
\hline
\end{tabular}

${ }^{1}$ Linear, quadratic and cubic order effects in relation to the increase of larvae/L.

${ }^{2} \hat{Y}=-3.632+9.15 \times X\left(r^{2}=0.97\right)$. 


\section{Discussion}

Stocking density is one of the most significant factors in the production systems for aquatic organisms. The use of adequate densities, considering the number of animals and/or the biomass in the tank, can increase production and consequently the profitability of the activity. In the present study, the increase in stocking density from 1 to 30 larvae/L was beneficial to optimise the structure and productivity of Nile tilapia larviculture.

Stocking density is directly related to growth, survival (Sanches \& Hayashi, 1999; Gall \& Bakar, 1999; El-Sayed, 2002; Ridha, 2006), homogeneity of the produced batch (Huang \& Chiu, 1997; Gall \& Bakar, 1999), welfare (Barcellos et al., 1999) and reproductive performance (Ridha \& Cruz, 1999) of the Nile tilapia, proving to be a factor that must be carefully assessed.

Contrary to the present study, El-Sayed (2002) tested densities between 3 and 20 tilapia larvae/L, feeding the animals three times per day with a diet containing $40 \%$ crude protein, for 40 days, found that the average weight and survival values were negatively correlated to the density increase, and 5 larvae/L was the density recommended. Tachibana et al. (2008) tested densities between 1 and 7 tilapia larvae/L, fed five times per day with a diet containing $48 \%$ crude protein for 30 days, and also observed reduction in growth with density increase. In another study, in which densities between 2 and 10 larvae/L were used in a green water system and with food containing $43 \%$ crude protein, given six times per day for 28 days, Sanchez \& Hayashi (1999) also reported growth reduction with storage density increase, and the recommended density was 2 larvae/L. However, in the studies of Sanches \& Hayashi (1999) and Tachibana et al. (2008), survival was similar for the different densities tested, and the biomass produced was directly related to the stocking density, which are data similar to the present study. Despite the differences discussed in the growth and survival during the larviculture of tilapia kept at different stocking densities, it is evident that higher densities produce more biomass per volume. This fact was also observed for the larviculture of other freshwater species such as pacamã Lophiosilurus alexandri (Luz \& Santos, 2008) and Hoplias lacerdae (Luz \& Portella, 2005), where densities of up to 60 and 90 larvae/L, respectively, were used, and performance and survival were not affected. Considering that these species are carnivorous, and that their larviculture, compared with tilapia, presents more difficulties due to the need to use live food and to the occurrence of cannibalism, other studies aiming at increasing stocking density of Nile tilapia larviculture are recommend, along with better handling techniques.

Another important point is that Nile tilapia larviculture is usually done in freshwater, while for this study, saline water with $2 \mathrm{~g}$ of salt/L was used. The use of low levels of salinity in freshwater fish larviculture has been considered an interesting treatment for various species, such as $H$. lacerdae (Luz \& Portella, 2002), Pimelodus maculatus (Weigartner Zaniboni Filho, 2004), Pseudoplatystoma corruscans (Beux \& Zaniboni Filho, 2007; Santos \& Luz, 2009), L. alexandri (Luz \& Santos, 2008; Santos \& Luz, 2009), Prochilodus costatus (Santos \& Luz, 2009), Rhinelepis aspera (Luz \& Santos, 2010) and Piaractus mesopotamicus (Jomori et al., 2012), showing survival and performance results similar and/or higher than the ones observed in freshwater. Water salinity media can improve the osmotic balance between fish and their surroundings (Boeuf \& Payan, 2001; Garcia et al., 2007), stimulate feed intake (Luz et al., 2008) and prevent diseases and parasites (Altinok \& Grizzle, 2001; Garcia et al., 2007). Furthermore, adequate levels of salinity can also reduce the toxic effect of nitrogen compounds, such as ammonia and nitrite (Weirich et al., 1993; Sampaio et al., 2002). Thus, the water salinity in the intensive larviculture of Nile tilapia may have contributed to improving the welfare of larvae and fingerlings and to decreasing the toxicity of the nitrogenous compounds.

Despite the fact that ammonia can directly affect fish development (Di Giulio \& Hinton, 2008), it has been shown to have a positive correlation to density increase during the larviculture of Nile tilapia. In the present study, the concentrations of total ammonia nitrogen $(0.2$ to $1.3 \mathrm{mg} / \mathrm{L})$ did not affect the initial development of Nile tilapia. It is worth stressing that these were not constant concentrations, i.e., the values represent the total ammonia nitrogen during the period between the water replacement at the end of the day and that of the next morning, when approximately $80 \%$ of the tank volume was renewed. In fact, fingerlings Nile tilapia with an initial average weight of $20 \mathrm{~g}$ only showed a decrease in growth rate when they were exposed to ammonia concentrations between 2.5 and $5 \mathrm{mg} / \mathrm{L}$ (El-Shafai et al., 2004), which were levels higher than those recorded in this study. According to Eddy (2005), for freshwater fish, the toxic concentration of ammonia may range from 0.068 to $2.0 \mathrm{mg} / \mathrm{L}$ and it depends on the interaction with other parameters, such as salinity, temperature and $\mathrm{pH}$. Similar results, with a direct relationship between ammonia and stocking density, were also observed in the larviculture of Atlantic cod, Gadus morhua (Baskerville-Bridges \& Kling, 2000), H. lacerdae (Luz \& Portella, 2005), P. corruscans 
(Campagnolo \& Nuñer, 2006) and L. alexandri (Luz \& Santos, 2008), suggesting the need for greater care, such as more frequent water exchange or the introduction of other systems for breeding such as water recirculation as production intensifies.

As stocking density increased, the levels of dissolved oxygen and turbidity also changed. The reduction in dissolved oxygen levels, however, from 8.3 to $7.1 \mathrm{mg} / \mathrm{L}$ for the lowest and the highest density, respectively, remained adequate for the fish. According to Delaney \& Klesius (2004), a dissolved oxygen concentration below $4.9 \mathrm{mg} / \mathrm{L}$ is stressful for fingerlings Nile tilapia, increasing the levels of glucose and cortisol in the blood serum. The increase in the turbidity due to the density increase and, hence, the amount of feed provided, was not harmful to the larvae and fingerlings. This high turbidity, however, made daily cleaning more difficult due to the rearing system used, namely a static one. In intensive larviculture with recirculating aquaculture system using mechanical and biological filters, the problems of increased turbidity and ammonia concentrations could probably be minimised, and besides the control of salinity, further research is suggested in order to enhance the larviculture of tilapia Nile.

\section{Conclusions}

It is possible to increase the stocking density of Nile tilapia larviculture from 1 to 30 larvae/L if they are kept in saline water with $2 \mathrm{~g}$ of salt/L, since it has no effect on the performance and survival percentage during the first 28 days of exogenous feeding. Increasing the stocking density of Nile tilapia larviculture reduces water quality, especially total ammonia, dissolved oxygen and turbidity levels.

\section{Acknowledgments}

The authors would like to thank FAPEMIG, CNPq, $\mathrm{MCT} / \mathrm{CNPQ} / \mathrm{CT}-\mathrm{AGRO} / \mathrm{MPA}$ and PRPq-UFMG for granting scientific initiation grants and for their financial support.

\section{References}

ALTINOK, I.; GRIZZLE, J.M. Effects of low salinities on Flavobacterium columnare infection of euryhaline and freshwater stenohaline fishes. Journal of Fish Diseases, v.24, p.361-367, 2001.

AMERICAN PUBLIC HEALTH ASSOCIATION - APHA. Standard methods for the examination of water and wastewater. 21.ed. Washington, 2005. 1368p

BARCELLOS, L.J.G.; NICOLAIEWSKY, S.; DE SOUZA, S.M.G. et al. The effects of stocking density and social interaction on acute stress response in Nile tilapia Oreochromis niloticus (L.) fingerlings. Aquaculture Research, v.30, p.887-892, 1999.
BASKERVILLE-BRIDGES, B.; KLING, L.J. Larval culture of Atlantic cod (Gadus morhua) at high stocking densities. Aquaculture, v.181, p.61-69, 2000.

BEUX, L.F.; ZANIBONI FILHO, E. Survival and the growth of pintado (Pseudoplatystoma corruscans) post-larvae on different salinities. Brazilian Achives of Biology and Technology, v.50, p.821-829, 2007.

BOEUF, G.; PAYAN, P. How should salinity influence fish growth? Comparative Biochemistry and Physiology Part C, v.130, p.411-423, 2001.

CAMPAGNOLO, R.; NUÑER, A.P.O. Sobrevivência e crescimento de larvas de surubim, Pseudoplatystoma corruscans (Pisces, Pimelodidae), em diferentes densidades de estocagem. Acta Scientiarum, v.28, p.231-237, 2006.

CARVALHO, R.A.P.L.F.; LIMA, J.A.F.; SILVA; A.L.N. Efeito da densidade de estocagem no desempenho do matrinxã, Brycon cephalus (Günther, 1869), cultivado em tanques-rede no período de inverno. Boletim do Instituto de Pesca, v.24, p.177-185, 1997.

DELANEY, M.A.; KLESIUS, P.H. Hypoxic conditions induce Hsp70 production in blood, brain and head kidney of juvenile Nile tilapia Oreochromis niloticus (L.). Aquaculture, v.236, p.633-644, 2004.

DI GIUliO, R.T.; HINTON, D.E. The toxicology of fishes. In: Di GIULIO, R.T.; HINTON, D.E. (Eds.). The toxicology of fishes. Boca Raton, FL, 2008. 1071p.

EDDY, F.B. Ammonia in estuaries and effects on fish. Journal of Fish Biology, v.67, p.1495-1513, 2005.

EL-SAYED, A-F. M. Effects of stocking density and feeding levels on growth and feed efficiency of Nile tilapia (Oreochromis niloticus L.) fry. Aquaculture Research, v.33, p.621-626, 2002.

EL-SHAFAI, S.A.; EL-GOHARY, F.A.; NASR, F.A. et al. Chronic ammonia toxicity to duckweed-fed tilapia (Oreochromis niloticus). Aquaculture, v.232, p.117-127, 2004.

FAIRCHILD, E.A.; HOWELL, W.H. Optimal stocking density for juvenile winter flounder Pseudopleuronectes americanus. Journal of the World Aquaculture Society, v.32, p.300-308, 2001.

GALL, G.A.E.; BAKAR, Y. Stocking density and tank size in the design of breed improvement programs for body size of tilapia. Aquaculture, v.173, p.197-205, 1999.

GARCIA, L.O.; BECKER, A.G.; COPATTI, C.E. et al. Salt in the food and water as a supportive therapy for Ichthyophthirius multifiliis infestation on Silver catfish, Rhamdia quelen, fingerlings. Journal of the World Aquaculture Society, v.38, p.1-11, 2007.

GOMES, L.C.; BALDISSEROTTO, B.; SENHORINI, J.A. et al. Effect of density on water quality, survival and growth of larvae of the matrinxã, Brycon cephalus (Characidae), in ponds. Aquaculture, v.183, p.73-81, 2000.

HAYASHI, C.; BOSCOLO, W.R.; SOARES, C.M. et al. Exigência de Proteína digestível para larvas de tilápia do Nilo (Oreochromis niloticus), durante a reversão sexual. Revista Brasileira de Zootecnia, v.31, p.823-828, 2002.

HECTH, T.; UYS, W. Effect of density on the feeding and aggressive behaviour in juvenile African catfish (Clarias gariepinus). South African Journal of Science, v.93, p.537-541, 1997.

HOUDE, E. D. Food concentration and stocking density effects on survival and growth of laboratory-reared larvae of Bay Anchovy Anchoa mitchilli and Lined sole Achirus lineatus. Marine Biology, v.43, p.333-341, 1977.

HUANG, W.B.; CHIU, T.S. Effects of stocking density on survival, growth, size variation, and production of Tilapia fry. Aquaculture Research, v.28, p.165-173, 1997.

IRWIN, S.; HALLORAN, J.O.; FITZGERALD, R.O. Stocking density, growth variation in juvenile turbot, Scophthalmus maximus (Rafinesque). Aquaculture, v.178, p.77-88, 1999.

JOMORI, R.K.; LUZ, R.K.; PORTELLA, M.C. Effect os salinity on larval of pacu Piaractus mesopotamicus, a freshwater species. Journal of the World Aquaculture Society, v.43, p.423-432, 2011.

LUZ, R.K.; MARTÍNEZ-ÁLVAREZ, R.M.; PEDRO, N. et al. Growth, food intake regulation and metabolic adaptations in goldifish 
(Carassius auratus) exposed to different salinities. Aquaculture, v.276, p.171-178, 2008.

LUZ, R.K.; PORTELLA, M.C. Diferentes densidades de estocagem na larvicultura do trairão Hoplias lacerdae. Acta Scientiarum, v.27, p.95-101, 2005.

LUZ, R.K.; PORTELLA, M.C. Larvicultura de trairão (Hoplias lacerdae) em água doce e água salinizada. Revista Brasileira de Zootecnia, v.31, p.829-834, 2002.

LUZ, R.K.; SANTOS, J.C.E. Densidade de estocagem e salinidade da água na larvicultura do pacamã. Pesquisa Agropecuária Brasileira, v.43, p.903-909, 2008.

LUZ, R.K.; SANTOS, J.C.E. Effect of salt adition and feeding frequency on cascudo preto Rhinelepis aspera (Pisces: Loricariidae) larviculture. Journal of Applied Ichthyology, v. 26, p.453-455, 2010.

LUZ, R.K.; ZANIBONI FILHO, E. Larvicultura do mandiamarelo Pimelodus maculatus Lacépède, 1803 (Siluriformes: Pimelodidae) em diferentes densidades de estocagem nos primeiros dias de vida. Revista Brasileira de Zootecnia, v.31, p.560-565, 2002.

MAINARDES-PINTO, C.S.; FENERICH-VERANI, N.; CAMPOS, B.E.S. et al. Masculinização de tilápia-do-Nilo, Oreochromis niloticus, utilizando diferentes rações e diferentes doses de 17 $\alpha$-Metiltestosterona. Revista Brasileira de Zootecnia, v.29, p.654-659, 2000.

MEURER, F.; HAYASHI, C.; BOSCOLO, W.R. et al. Fontes protéicas suplementadas com aminoácidos e minerais para a tilápia-do-Nilo durante a reversão sexual. Revista Brasileira de Zootecnia, v.34, p.1-6, 2005.
RIDHA, M.T. Comparative study of growth performance of three strains of Nile tilapia, Oreochromis niloticus, L. at two stocking densities. Aquaculture Research, v.37, p.172-179, 2006.

RIDHA, M.T.; CRUZ, E.M. Effect of different broodstock densities on the reproductive performance of Nile tilapia, Oreochromis niloticus, in a recycling system. Aquaculture Research, v.30, p.203-210, 1999.

SAMPAIO, L.A.; WASIELESKY, W.; MIRANDA-FILHO, K.M. Effect of salinity on acute toxicity of ammonia and nitrite to juvenile Mugil platanus. Bulletin of Environmental Contamination and Toxicology, v.68, p.668-674, 2002.

SANCHES, L.E.F.; HAYASHI, C. Densidade de estocagem no desempenho de larvas de tilápia-do-Nilo (Oreochromis niloticus L.), durante a reversão sexual. Acta Scientiarum, v.21, p.619-625, 1999.

SANTOS, J.C.E.; LUZ, R.K. Effect of salinity and prey concentrations on Pseudoplatystoma corruscans, Prochilodus costatus and Lophiosilurus alexandri larviculture. Aquaculture, v.287, p.324-328, 2009.

TACHIBANA, L.; LEONARDO, A.F.G.; CORRÊA, C.F. et al. Densidade de estocagem de pós-larvas de tilápia-do-Nilo (Oreochromis niloticus) durante a reversão sexual. Boletim do Instituto de Pesca, v.34, p.483-488, 2008.

WEINGARTNER, M.; ZANIBONI FILHO, E. Efeito de fatores abióticos na larvicultura de pintado-amarelo Pimelodus maculatus (Lacépède, 1803): salinidade e cor de tanque. Acta Scientiarum, v.26, p.151-157, 2004.

WEIRICH, C.R.; TOMASSO, J.R.; SMITH, T.I.J. Toxicity of ammonia and nitrite to sunshine bass in selected environments. Journal of Aquatic Animal Health, v.5, p.64-72, 1993. 